\title{
OUTSOURCING AND ORGANISATIONAL EFFICIENCY OF ISSUES IN NIGERIA: RIVERS STATE UNIVERSITY AS A CASE STUDY
}

\author{
Yakie, Ebisidor Favour (M.Sc) \\ Department of Management, Faculty of Management Sciences \\ Rivers State University, Nkpolu Oroworukwo, P. M.B. 5080, Port Harcourt.
}

and

M.D. Tamunomiebi (PhD)

\begin{abstract}
This paper is a theoretical paper, and its purpose was to discuss literature on the relationship between outsourcing and organizational efficiency. The paper offers a detailed assessment of outsourcing and its implications for organizational operations and functionality. The resource-based theory was adopted as the theoretical foundation for the study, and it offered a strong position in support of the imperatives of focusing on key assets and responsibilities as a way of enhancing organizational efficiency and ultimately competitiveness. The position reached based on the congruence of views, specifies outsourcing as commendable and required for the efficient functioning of organizations today. On this note, it was concluded that the features of cost and organizational operations are efficiently addressed through the adoption of outsourcing practices and behaviour which are strategic and which allow for the organizations focus on its own key and primary functions. The study also recommended that the practice of outsourcing should be such that emphasizes more on the additional functions and areas identified as weak or overly costly to the organization. Such features can be addressed through a shift in responsibilities to other organizations which are more proficient and structured for that purpose.
\end{abstract}

KEYWORDS: Organizational efficiency, outsourcing, operations, cost, resources

\section{INTRODUCTION}

Organizations have always sought ways to obtain and maintain efficient processes and operations as a form of competitive advantage over their competitors; however, with the increased movement towards a single globalized economy, this desire is even more prevalent for businesses today. One avenue that firms have pursued to enhance their efficiency levels in this new business environment has been to increase the role of outsourcing in their operations, which has been argued to provide a competitive advantage through heightened levels of efficiency to these firms (Monczka \& Trent, 2008; Quinn \& Hilmer, 2004).

In the early 80's the manufacturing industry was the leading business activity in most African countries, both in terms of size and employment. The industry was known to employ a large proportion of farming households and about $30 \%$ of the entire labour force within most African countries in their various national manufacturing sectors. Unfortunately, the subsector however started declining in the mid-1980s within most African countries such as Nigeria and Kenya until the 1990s (Export Processing Zone, 2011). Efforts to spur growth in the manufacturing industry have been considered with outsourcing being one of the most recommended strategies. 
Dwindling resources and market competitiveness have also forced organizations to scrutinize their methods of producing goods and services and make changes in their processes in order to maximize economic returns. To survive and enhance their revenues within the current globalization era, organizations have pursued continuous improvement, leaned up production, reengineered business processes, and integrated supply chains (Harris, 2008). Over the past decades there is a growing realization of the important contribution of the outsourcing strategy on organizational outcomes, most especially efficiency (Nayak, 2007).

While many firms have followed the pattern of outsourcing some part of their operations to improve their competitiveness, others have not, leading many to ask about the implications of outsourcing on the functionality, especially with regards to efficiency of organizations (Merino and Rodriguez, 2007; Nayak, 2007). In general, outsourcing is considered to be that part of an organization's process, wherewith it sources from outside suppliers, regardless of the type of relation with these suppliers (Mol et al., 2005). As such, every firm engages in outsourcing to some degree, be it manufacturing, customer care, logistics, post sales technical support, finance, auditing, staffing, or design. The choice of what functions to outsource and which to keep in-house is based on the need to develop skills, invest in resources, and stay abreast of evolving technology in any areas kept in-house (Harris, 2008).

In studies examining the impact of outsourcing, there have been several key advantages of outsourcing identified, such as cost savings (Nayak, et al., 2007), reduced capital investment within the firm (Gilley and Rasheed, 2000), improved responsiveness to changes in the business environment and improvement on service delivery (Dess et al., 2005), an increased focus on core competencies (Kotabe and Murray, 2009), increased competition among suppliers ensuring higher quality goods and services in the future, and a reduced risk of changing technology (Quinn, 2000). This study further contributes by assessing the role of outsourcing on the overall efficiency of organizations. The purpose of the paper is to offer a more indepth assessment of the nature and implications of outsourcing for organizations.

\section{REVIEW OF LITERATURE}

\section{Theoretical Foundation - Resource-based Theory}

The resource-based view of the firm (RBV) is adopted as the theoretical baseline for this study as it provides an important framework for explaining and predicting the basis of a firm's competitive advantage and performance through its emphasis on its own resources and core as well as unique activities (Barney et al. 2011; Slotegraaf et al. 2003; Vorhies \& Morgan 2005). According to Peteraf and Barney (2003), a firm achieves a competitive advantage when it is able to generate "more economic value than the marginal (breakeven) competitor in its product market" implying an emphasis on first attaining cost-efficient processes and operations. A firm has achieved a sustained competitive advantage (SCA) "when it is creating more economic value than the marginal firm in its industry and when other firms are unable to duplicate the benefits of this strategy" (Barney \& Clark 2007). The resource-based theory offers an explanation for the imperatives of focus on one's own resources and key strength, thus suggesting that outsourcing areas of weakness or low functional capacity may proof to be more advantageous, as it offers the organization improved focus on its area of expertise. 
The resource-based theory also relies on two fundamental assumptions about firm-based resources to explain how they generate competitiveness and why some firms may persistently outperform others. First, firms possess different bundles of resources, even if they operate within the same industry (Peteraf \& Barney 2003). This offers them a pool of options and assets to utilize; second, the firm can drive their performance and competitiveness through their focus and emphasis on its own key strengths and expertise and by this, it can outsource other functions or operations which may appear more complicated or inefficient to run.

\section{Outsourcing}

Early descriptions of outsourcing typically referred to the situation in which organizations expanded their purchases of manufactured physical inputs, like car companies that purchased window cranks and seat fabrics from outside the firm rather than making them inside (Bhagwati, et al. 2004). A number of recent scholars have argued that enterprises will improve efficiency by concentrating on their core functions and outsourcing all peripheral activities to firms that specialize in such tasks (Cannon, 2009; Harrison \& Kelley, 2003).

The increasing use of contractors, for the supply of components and services, has been one of the notable trends in work organization over the past decade (Mayhew, Quinlan \& Bennett, 2006). As Benson and Ieronimo (2006) reported most organizations surveyed in their study had outsourced at least one activity with most planning further outsourcing within the next three years. This finding is supported by Wooden and Vanden Heuvel (2006) in their own investigation who found that 90 per cent of the 522 workplaces surveyed had used contractors in the past year.

The concept of outsourcing is not a recent phenomenon. This is as organizations have been outsourcing since the early 1900s, although under a variety of labels (Cappelli, 1995; Chandler, 2004). The activities outsourced, however, were not generally central to the core objectives of the firm and usually made a low contribution to the value chain. Conventional wisdom was that outsourcing core activities or technologies would threaten the organization's competitive advantage (Bettis, Bradley \& Hamel, 2009). The success of companies like Microsoft, Benetton and Nintendo has, however, demonstrated that a competitive advantage can be achieved through outsourcing arrangements. These firms have outsourced many of the traditionally perceived core competencies including product design, software development and distribution.

Many of these firms are recent and can be considered as emerging from the current global market dynamics and so are free from historical practices and cultural restraints. According to Quinn (2000) all firms must re-examine their entire value chain and outsource those activities found not to be at a 'world class' standard. Mature firms are now beginning to appreciate that their current organizational arrangements may no longer be suitable for their key competencies. Indeed, significant advantages, such as lower costs, lower production and market times, and improved innovation, may result from market-based relationships (Stalk, 2008). This has led to an increasing number of firms outsourcing their key competencies and capabilities (Piore \& Sabel, 2004).

Quinn (1999) argued that outsourcing is the process of engaging the services of a provider to manage essential tasks that would otherwise be managed by in-house personnel. This, when 
properly done, allows a business to plan the optimal utilization of its resources and capabilities to achieve the best advantage. It also improves the achievability of an organization's strategic goals. This kind of outsourcing strategy can be utilized by any organization regardless of its size and has the effect of not only reducing the cost of operation but also providing an opportunity for optimal allocation of resources to the very necessary functions (Welch \& Nayak, 1992).

Yet despite these developments little is known about the long-term consequences of mature firms pursuing a flexibility strategy based on outsourcing. Results from recent studies are now emerging which point to higher health and safety risks under an outsourcing strategy (Kochan et al, 2004; Mayhew, et al, 2006). These are important factors to consider when opting for outsourcing as unlike many of the other management strategies of the last decade it will be, in many cases, difficult for firms to reverse the process. In part, this is due to the nature of the contracts entered into and, in part due to the loss of the key skills necessary to perform the particular function.

The general outsourcing model developed by Arnold (2000) illustrates that there are four components which need to be reviewed when making outsourcing decisions: outsourcing subject, outsourcing object, outsourcing partner, and outsourcing design initially, organizations should focus on outsourcing the subject, which involves the decision making process to determine if outsourcing is a viable option. Organizations should then consider which internal activities might be outsourced. Outsourcing objects refers to the activity which might be outsourced and is linked to the degree of manufacturing penetration with respect to organization activities, including core activities, core-close activities, core-distinct activities, and disposable activities.

Arnold (2000) states that if the activity is a core competency, highly specific and important for organizational strategy, it makes no sense to outsource these kinds of activities. Next, organizations should consider an outsourcing partner from all possible outsourcing providers. Finally, when outsourcing internal activities, organizations need to formulate the most appropriate outsourcing design. In addition to this, Arnold (2000) suggests that organizations should focus on three major governance structures when making outsourcing decision. These include the price of external services, management control, and other governances, including contracts or strategic alliances. Despite addressing specific decision making with regard to outsourcing, this model places no regard on employee involvement.

The basic idea behind outsourcing is to improve on the organizations cost and control measures by allowing outside providers and specialists to take over the operation and management of a given function, thus facilitating improved focus on their key functions. Such advantages may come in different forms such as improving the bottom line of a company by reducing various operating expenses and increasing the flexibility for innovation without having to invest too much in training and capital infrastructure (Mella \& Pellicelli, 2012). Other benefits may come in form of convenience, where the strategy allows the business owners and managers to concentrate on their core business (Insinga \& Werle, 2000). As a simple rule, so long as the benefits are considered sufficient by the client, then the process of strategic outsourcing can be considered a success. 


\section{Organizational Efficiency}

Kovac (2007) described organizational efficiency as the positive result of the comparison between the inputs and the results obtained. Mandl et al. (2008) and Sorber (1999) posit that efficiency is the relationship between inputs and effects; therefore, efficiency shows effects regardless of the inputs or resources needed to achieve the objectives. Robbins and Coulter (2005) state that efficiency means obtaining the greatest possible output out of the smallest quantities of inputs. The relevant literature describes different methods of the measurement of organizational efficiency.

Mandl et al. (2008) argued that organizational efficiency cannot be measured directly; therefore, different approaches to data and methodological framework are required in its measurement. According to Koh and Saad (2007), benchmarking or comparative analysis are frequently used methods. Rolstadas (1995) posits a systematic, iterative process of evaluation and selection the leading organizations in the industry. For the efficiency measurement, there is no one single method. The Common Assessment Framework (CAF) is one benchmarking method; it is a total quality management tool developed by the public sector for the public sector, inspired by the Excellence Model of the European Foundation for Quality Management $(\mathrm{EFQM})$. It is based on the premise that excellent results in organisational performance, citizens/customers, people, and society are achieved through leadership driving strategy and planning, people, partnerships, resources, and processes. It looks at the organisation from different angles simultaneously (EIPA, 2013).

Aristovnik (2012) stated that the CAF is easy to use and takes into account the particularities of both private and public sector organizations (the impact of the policy, professional work, customer orientation, non-financial results). Aristovnik (2012) further emphasized that the optimal effects of the assessment are achieved if a self-assessment principle is used, because 'the employees knew the organization the best', but a credible outcome requires a critical review. In connection with employee efficiency, Abdolreza et al. (2013) studied wage flexibility. They determined that wage and salary factors have a great effect on efficiency. Likewise, Wright and Davis (2003) determined that higher levels of cost control and efficiency has an impact on improved productivity.

In their research, Dessler (1993), Guest (2004), Egger-Peitler et al. (2007), Wanyama and Mutsotso (2010), Talebi et al. (2012), determined that evidence of efficiency and monitoring of functions in a way that controls for waste impacts positively on productivity of the employees and increases their loyalty to the organization. This is as salaries, employment security, security and health at work, possibilities regarding education and promotion also have an impact on organizational efficiency. Baptiste (2008) and the Regus Global Report (2011) argued that the structuring of systems in a more harmonized and economic way offers higher productivity and loyalty to the organization. In their research, Helpern (2005), Kossek (2005), Rowlattova et al. (2006), Davis and Kalleberg (2006), Kelly et al. (2008), Kossek and Hammer (2008), Kossek and Michel (2010) and the Regus Global Report (2011) studied flexibility in relation to the organizational efficiency and ascertained that there exists a significant correlation. 


\section{Outsourcing and Organizational Efficiency}

For organizations seeking to simply lower their cost of doing business, and the efficiency of their processes and operations, outsourcing is the most traditionally acknowledged driving force for cost reduction (Blumberg, 1998). Some organizations may outsource only for cost reduction and efficiency especially those that are involved in offshore outsourcing to destinations of lower cost. As the business environment changes rapidly and customers increasingly modify their demands, organizations have to find a way to stay afloat in the market by providing innovative products to the market in proper time and ahead of competition (Calantone \& Stanko, 2007). Such organizations may therefore utilize strategic outsourcing with a goal of developing new products faster as they seek increased flexibility for innovation (Gesing, Antons, Piening, Rese \& Salge, 2014). The other major driver for outsourcing is the need to focus on core competencies.

According to Buchanan (2014), the ability to free up organizational resources and capabilities so as to focus on the organization's core business is one of the greatest determinants of whether outsourcing can be considered as strategic or not. Firms therefore utilize outsourcing in a bid to reduce the administrative burden of managing support activities so as to focus their efforts on top business priorities (Cheng et al, 2014).

Outsourcing contributes to all forms of flexibility; wage, functional and numerical. Outsourcing involves 'the purchase of goods or services that was previously provided internally' (Lacity \& Hirschheim, 2003). Thus, management by outsourcing can achieve considerable flexibility as payment is made only for work undertaken and completed, the tasks undertaken are contract-related and not craft-related, and worker numbers can be adjusted to the requirements of the plant. This last issue is particularly relevant to those firms that experience fluctuations in demand for their major product or service.

By outsourcing enterprises are free to direct the released physical, managerial and financial resources to producing a quality product or service at a competitive price. Outsourcing can thus be a form of strategic flexibility where the firm adopts a different form of workplace organization in an endeavour to improve enterprise performance. Nevertheless, while outsourcing can improve efficiency, the arguments for adopting this practice have tended to focus on cost considerations (McCune, 2003). Plunkett (2008) reported that outsourcing is usually implemented to save money rather than forming part of any coherent strategy. Tully (2003) contended, however, that outsourcing frees companies to direct scarce capital where they have a competitive advantage. This raises the question of strategy, although Strassman (2007) concluded that for most companies strategy is not driving outsourcing' but rather 'they're in financial trouble.

Abraham and Taylor (2006) found only limited evidence that the search for lower costs was driving outsourcing, although the outsourcing of lower skilled activities appeared to be motivated by a desire to reduce hourly labour costs. Similarly, Wooden and VandenHeuvel (2006) found accessing specialized skills, coping with peak periods, and the ability to deal with one off task were the major reasons workplaces had used contract labour. As Sharpe (2007) argued outsourcing enables organizations to gain the benefit of state-of-the-art skills and technologies without investing directly in their development or exposing themselves to more risk than they care to take on'. 
Abraham and Taylor (2006) found support for this proposition in that smaller enterprises were likely to have outsourced more highly skilled activities. Outsourcing may also be an impetus and agent for change. Contractors can bring to the organization more specialized and efficient ways of undertaking the given tasks (Sharpe, 2007). This is particularly important if the enterprise has work practices that are no longer relevant or economically sustainable. In addition, outsourcing enables the benchmarking of activities across firms (Sharpe, 2007).

Another advantage resulting from outsourcing may be improved industrial relations that result from shifting industrial relations responsibility to a third party. This can be the case where the union representing the employees currently providing the service is militant or where workplace reforms are being resisted. Unions, for their part, have expressed concern about the shift to market-mediated employment arrangements and as Kosters (2007) pointed out, these practices can make enforcement more difficult for requirements like those for minimum wages or overtime pay, thus impacting negatively on the cost of running the organization. Nevertheless, Harrison and Kelley (2003) found no evidence that subcontracting is associated with union avoidance per se.

Outsourcing can also generate needed cash when firms sell assets or transfer employees to vendors (Juma'h and Wood, 2003). Cost advantages may come from reducing or eliminating new investments or investment renewals (Gilley \& Rasheed, 2000). This occurs, for instance, when vendors offer services using technologies that are more efficient than the client's or skills that are unjustifiably costly for client develop in house (Abraham \& Taylor, 2006). In addition, outsourcing may reduce internal cost inefficiencies associated with administration, bureaucratic procedures, and politics (Gilley \& Rasheed, 2000).

Outsourcing when approached in a proper manner can lead to a vital combination of reducing both costs and risks. This is because the outside suppliers undertake investments and development risks that the outsourcer avoids. Therefore, by sharing these risks among multiple clients, the supplier lowers costs for all its clients due to the pooling effect and economies of scale. Additionally, risk management in itself is now becoming one of the critical new tools and benefits of outsourcing (Gilley and Rasheed, 2000).

In most cases, an organization may find that the extent of relationship required to absorb a strategic suppliers' strong technical capabilities may lead to increased coordination costs or may increase the possibility of unintended technology leakage. Such organizations may therefore avoid these costs by outsourcing technical capabilities from strong strategic partners. For instance, strategic suppliers with strong technical capabilities will often be developing new sticky knowledge that firms will find difficult to access and costly to transfer across interorganizational boundaries, even when they seek to develop relationship-specific absorptive capabilities (Gilley \& Rasheed, 2000).

\section{CONCLUSION}

The views expressed in this paper, capture the key attributes and relationships between outsourcing and organizational efficiency. The theories discussed offer descriptions of the features, antecedents and possible outcomes of each of the variables. Going by a generalization of the literature, there appears to be strong support for the adoption of outsourcing as a 
necessary premise in the enhancement of organizational efficiency, within both private and public sector organizations. In line with this position, this paper concludes by asserting that the features of cost and organizational operations are efficiently addressed through the adoption of outsourcing practices and behaviour which are strategic and which allow for the organizations focus on its own key and primary functions.

\section{Recommendations}

This paper recommends as follows:

i. The practice of outsourcing should be such that emphasizes more on the additional functions and areas identified as weak or overly costly to the organization. Such features can be addressed through a shift in responsibilities to other organizations which are more proficient and structured for that purpose.

ii. Outsourcing should also be carried out based on the strict monitoring and control of such activities by the organization itself. As such, all attributes and functions outsourced must comply and be in line with the specified standards and formats required by the organization itself.

iii. The conditions and features of partnerships that lead to outsourcing should also be clearly spelt out in a way that clearly defines the relationship. This drives the sustainability and quality of such relationships and limits occasions or events of misinterpretation of expectations between the parties or organizations involved.

\section{References}

Abraham, K. and Taylor, S. (2006). Firms use of outside contractors: Theory and evidence, Journal of Labor Economics, 14 (3): 394-424.

Aksoy, A. \& Öztürk, N. (2012). The fundamentals of global outsourcing for manufacturers, manufacturing system, Retrieved October 2, 2014, from http://www.intechopen.com/books/manufacturing-system/

Aristovnik, A., (2012). Vzpostavitev sistema merjenja učinkovitosti, uspešnosti in kakovosti v slovenski policiji. Ciljno raziskovalni projekt. Končno poročilo raziskave. [Establishment of the system for the efficiency, effectiveness and quality measurement, in the Slovenian police. Targeted Research Project. Final report of the research]. Retrived 05. 12. 2012 from http:// www.mnz.gov.si/fileadmin/mnz.gov.si/pageuploads/ SOJ/word/Tacen_15112012/CRP_koncno_porocilo_ V5-1037_.pdf

Arnold, U. (2000). New dimension of outsourcing: a combination of transaction cost economics and the core competencies concept. European Journal of Purchasing \&Supply Management, 6, 23-29.

Bettis, R., Bradley, S., and Hamel, G. (1992). Outsourcing and industrial decline, Academy of Management Executive, 6(1)

Bhagwati B, Jagdish C., \& Bugger, G (2004). The muddles over outsourcing, The Journal of Economic Perspectives, 18(4), 93-114.

Blumberg, D. F. (1998). Strategic assessment of outsourcing and downsizing in the service market. Managing Service Quality, 8 (1), 5-8

Buchanan, L. (2014). Built to last forever. Inc. Magazine, 48-53

Calantone, R. J. \& Stanko, M. A. (2007). Drivers of outsourced innovation: An exploratory study. Journal of Product Innovation Management, 24 (3), 230-241.

Cannon, D. (2009). Keeping outsourcing in hand, Chief Executive, 38-41. 
International Journal of Management Technology

Vol.7, No 1, pp. 20-30, January 2020

Published by ECRTD-UK

Print ISSN: ISSN 2055-0847(Print), Online ISSN: ISSN 2055-0855(Online)

Cappelli, P. (1995). Rethinking employment, British Journal of Industrial Relations, 33 (4), 563-602.

Chandler, M. (2004). Management rights and union interests, McGraw-Hill, New York

Cheng, L. C. (2011). Assessing performance of utilizing organizational modularity to manage supply chains: Evidence in the US manufacturing sector. International Journal of Production Economics, 131 (2), 736-746

Cheng, L., Cantor, D. E., Grimm, C. M. \& Dresner, M. E. (2014). Supply chain drivers of organizational flexibility - A study of U.S. Manufacturing industries. Journal of Supply chain management, 50 (4), 62-75

Davis, A., \& Kalleberg, A. (2006). Family friendly organizations: Work and family programms in the 1990. Work and Occupations, 33(2), 191-223

Dess, G. G., Rasheed, A. McLaughlin, K., and Priem, R. (1995). The new corporate architecture, Academy of Management Executive, 9(3),

Dessler, G. (1993). Winning commitment. New York: McGraw Hill.

Egger-Peitler, I., Hammerschmidt, G., \& Meyer, R., E., (2007). Motivation, identification and incentive preferences as issues for modernisation and HR strategies in local government. First evidence from Austria. The proposed paper forms part of a research project Public service motivation characteristics of motivation in public administration and opportunities for improving incentives in public management, Funded by the 'Jubiläumsfonds der Stadt Wien'. Retrieved 15. 12. 2014 from https://soc.kuleuven.be/io/egpa/HRM/madrid/ Hammerschmid\&Meyer2007.pdf

EIPA (2013). The common assessment framework (CAF). Improving public organisations through self-assessment. CAF 2013. Retrieved 05. 12. 2012 from http://www.eipa.eu/files/File/CAF/CAF_2013. pdf

Gesing, J., Antons, D., Piening, E. P., Rese, M. \& Salge, T. O. (2014). Joining forces or going it alone? On the interplay among external collaboration partner types, inter-firm governance modes, and internal R\&D. Journal of Product Innovation Management, 10, 1111

Gilley, K. M. \& Rasheed, A. (2000). Making more by doing less: An analysis of outsourcing and its effects on firm performance, Journal of Management, 26(4).

Halpern, D. F. (2005). How time-flexible work policies can reduce stress, improve health and save money. Stress and Health. 21, 157-168

Harris. P. (2008). Outsourced learning: A new market emerges, Training and Development, 57(9). 30-38

Harrison, B. \& Kelley, M. (2003). Outsourcing and the search for flexibility, Work, Employment \& Society, 7 (2), 213-235.

Juma'h, A. H., \& Wood, D. (2003). The price sensitivity of business service outsourcing announcements by UK companies. International Journal of Information Technology \& Decision Making, 2, 161-180

Kochan, T., Smith, M., Wells, J. \& Rebitzer, J. (2004). Human resource strategies and contingent workers: The case of safety and health in the petrochemical industry, Human Resource Management, 33 (1), 55-77.

Koh, S., C., \& Saad, L., S., M. (2007). Benchmarking the management of operations and informations systems. New York: Emerald Group Publishing. 
International Journal of Management Technology

Vol.7, No 1, pp. 20-30, January 2020

Published by ECRTD-UK

Print ISSN: ISSN 2055-0847(Print), Online ISSN: ISSN 2055-0855(Online)

Kossek, E., E., \& Michel, J., S. (2010). Flexible work schedules. In: Zedeck, S. (ed). APA Handbook of industrial and organizational psychology. American Psychological Association, Washington DC.

Kossek, E., Hammer, L. (2008). Work/Life training for supervisors gets big results. Harward Business Review, November

Kosters, M. (2007). New employment relationships and the labor market, Journal of Labor Research, 18 (4), 551-559.

Kotabe, M. \& Murray, J. (2000). Linking product and process innovations and modes of international sourcing in global competition: A case of foreign multinational firms, Journal of International Business Studies, 3,

Kovac, P. (2007). Podjetniški koncepti kot gibalo modernizacije slovenske javne uprave. [Business concepts as the driver of the modernization of Slovenian public administration]. In: Ferfila, B. et al. Ekonomski vidiki javnega sektorja, University of Ljubljana, Faculty of Social Sciences, 94-265

Lacity, M. \& Hirschheim, R. (2003). Information systems outsourcing, Wiley, New York,

Mandl, U., Dierx, A., \& Ilkovitz, F. (2008). European economy. The effectiveness and efficiency of public spending. Economic and Financial Affairs, European Commission, Economic Papers 301

Mayhew, C, Quinlan, M. \& Bennett, L. (2006). The effects of subcontracting/ outsourcing on occupational health and safety, Industrial Relations Research Centre, Monograph, 38, University of New South Wales

McCune, J. (2003). Thin is in, Small Business Reports, 30-40.

Merino, F. \& Rodriguez, D. R. (2007). Business services outsourcing by manufacturing firms, Industrial and Corporate Change, 16(6), 1147-1173

Mol, M. J., Tulder, R. J., \& Beije, P. R. (2005). Antecedents and performance consequences of international outsourcing, International Business Review, 14(5), 599-617.

Monczka, R. \& Trent, R. J. (2008). Global sourcing: A development approach, International Journal of Purchasing and Materials Management, 27(2), 2-8.

Nayak, J. K., Sinha, G., \& Guin, K. K. (2007). the determinants and impact of outsourcing on small and medium enterprises--an empirical study, IIMB Management Review, 19(3), 277-284.

Piore, M. \& Sabel, C. (2004). The second industrial divide: Possibilities for prosperity, Basic Books, New York.

Plunkett, S. (2008). Outsourcing: A new way to save, Business Review Weekly, 1, 8-10, 14.

Quinn, B. J., \& Hilmer, E G. (2004). Strategic outsourcing. Sloan Management Review, 35(4), 43-55.

Quinn, J.B. (2000). Strategic outsourcing: Leveraging knowledge capabilities. Sloan Management Review, 40(4), 9-21.

Robbins, S., P., \& Coulter, M. (2005). Management. Pearson Prentice Hall, New Jersey.

Rolstadas, A. (1995). Enterprise modelling for competitive manufacturing, control engineering practice. Swedish Standards Institute, 3, 43-50

Rowlatt, A., et al. (2006). Flexible working: working for families, working for business. A Report for the Family Friendly Working Hours Taskforce. The Women and Work Commission, shaping a fairer future. Retrieved 10. 12. 2012 from http://www.dwp.gov.uk/ docs/family-friendly-task-force-report.pdf

Sharpe, M. (2007). Outsourcing, organizational competitiveness, and work, Journal of Labor Research, 18 (4): 535-549. 
Sorber, B. (1999). Performance measurement in the central government departments of Netherlands. In: Halachmi A. (ed.) Performance and quality measurement in government. Issues and experiences, Chatelaine Press: 23-33

Stalk, G. (2008). 'Time-the next source of competitive advantage, Harvard Business Review, 9 (4), 41-51.

Strassman, P. (2007). Outsourcing: A game for losers, Computerworld, 21, 1-3

Talebi, B., Pakdelbonab, M., Zemestani, G., \& Aghdami, N. (2012). Investigation the relationship between the employee's quality of work life (QWL) and their effectivness in banking. European Journal of Experimental Biology, 2(5), 1839-1842.

Tully, S. (2003) The modular corporation, Fortune, 8, 106-115.

Wanyama, K., W., \& Mutsotso, S. N. (2010). Relationship between capacity building and employee productivity on performance of commercial banks in Kenya. African Journal of History and Culture, 2(5), 73-78

Wooden, M. \& VandenHeuvel, A. (2006). The use of contractors in Australian workplaces, Labour Economics and Productivity, 8 (2), 163-194. 